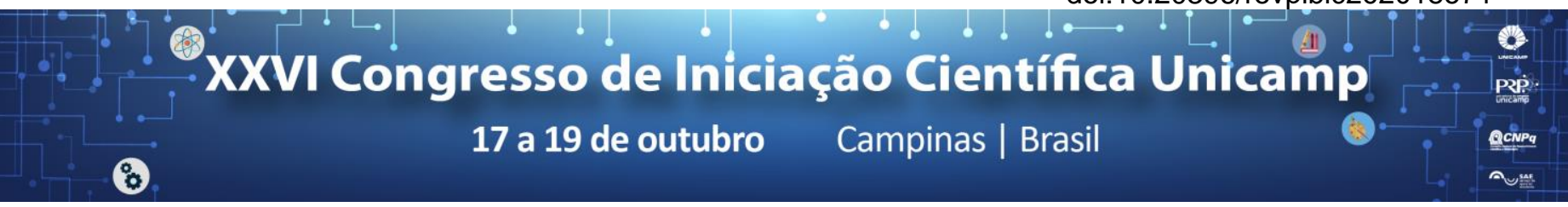

\title{
Degradação do 2,4 Diclorofenol em rede de distribuição de água por Ozônização.
}

\section{Gustavo A. Brugnera*, Renato F. Dantas.}

\section{Resumo}

Este trabalho teve como objetivo testar o potencial da ozonização para a limpeza de rede de distribuição de água atravéz da degradação do 2,4 diclorofenol, usado como composto modelo, visando o desenvolvimento de protocolo de limpeza em caso de ataques terroristas. A aplicação de ozônio na rede contaminanda conseguiu mais de $90 \%$ de remoção dos agentes químicos testados.

\section{Palavras-chave:}

Processos Oxidativos, Ozônio, limpeza de rede.

\section{Introdução}

Existem muitas maneiras de exemplificar a crueldade do ser humano quanto a si próprio, e uma delas é o terrorismo, que mesmo que em alguns casos não leve a morte, pode causar danos irreparáveis as vítimas. O uso de armas químicas neste caso é algo comum, seja ela como gás ou envenenamento da água, tornando redes de distribuição de água vulneráveis à ação de grupos terroristas.

O uso de clorofenóis como compostos modelo de ataque justifica-se pela facilidade de aquisição, além de serem muito tóxicos e possuírem certa reatividade com o ozônio (1), possibilitando assim o estudo da sua degradação. Apesar de não haver histórico de contaminação por esse tipo de contaminantes em redes de abastecimento, o estudo de sua eliminação pelo ozônio permite o desenvolvimento de protocolo de limpeza de agentes químicos com toxicidade e reatividade semelhantes.

O objeivo principal desse estudo foi testar a aplicação do ozônio para eliminação de agentes químicos de redes de abastecimento, testando principalmente como composto modelo o 2,4 diclorofenol e alguns casos também o corante azul de metileno.

\section{Resultados e Discussão}

A primeira etapa do estudo foi a construção de uma rede de distribuição de água em escala de laboratório. A rede foi construída com 100 metros de comprimento, contando com cinco pontos de coleta e um reservatório com 360 litros de capacidade. A injeção de ozônio na rede foi feita por injeção por venture e o ozônio foi produzido por um ozonizador (Ozonar, Brasil).

Figura 1. Simulador de rede de distribuição de água.

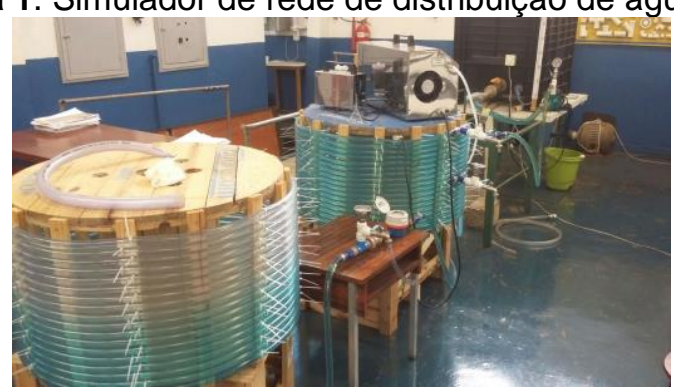

Para a realização do estudo de degradação do composto 2,4 diclorofenol houve a necessidade de comprovar se a adição do mesmo na rede não mudaria parâmetros como condutividade, $\mathrm{pH}$ e turbidez. Foi comprovado que 10 $\mathrm{mg} / \mathrm{L}$ do composto não provocava alteração nesses parâmetros.
Após o termino da $1^{\circ}$ etapa, prosseguiu-se com os estudos da contaminação da rede, utilizando primeiramente azul de metileno como composto modelo (Tabela 1). Pôde-se verificar que o ozônio conseguiu chegar ao longo de toda a rede e limpar mais de $90 \%$ do composto em cerca de 90 minutos.

Tabela 1. Degradação do azul de metileno

\begin{tabular}{|c|c|c|c|}
\hline $\begin{array}{c}\text { Tempo } \\
(\mathrm{min})\end{array}$ & $\begin{array}{c}\text { Absorbância } \\
(600 \mathrm{~nm})\end{array}$ & $\begin{array}{c}\text { Concentração } \\
\text { de azul de } \\
\text { metileno } \\
(\mathrm{mg} / \mathrm{L})\end{array}$ & $\begin{array}{c}\text { Dosagem } \\
\text { de O3 } \\
(\mathrm{mg} \mathrm{de} \mathrm{O}\end{array}$ \\
\hline 0 & 0,871 & 1,132 & 0 \\
\hline 18 & 0,483 & 0,626 & 9,5 \\
\hline 36 & 0,312 & 0,403 & 19,1 \\
\hline 54 & 0,194 & 0,249 & 28,5 \\
\hline 72 & 0,117 & 0,148 & 38,1 \\
\hline 90 & 0,071 & 0,088 & 47,5 \\
\hline
\end{tabular}

Após verificar que o ozônio podia alcançar os diferentes locais da rede, foi testada a eliminação do 2,4 diclorofenol, tal como mostrado na Tabela 2.

Tabela 2. Degradação do 2,4 diclorofenol.

\begin{tabular}{|c|c|c|}
\hline $\begin{array}{l}\text { Tempo } \\
\text { (min) }\end{array}$ & $\begin{array}{l}\text { Dosagem de } \mathrm{O}_{3} \\
\left(\mathrm{mg} \mathrm{de}_{3}\right)\end{array}$ & $\begin{array}{l}\text { Concentração de Cloro } \\
\text { residual }(\mathrm{mg} / \mathrm{L} .)\end{array}$ \\
\hline 0 & 0 & 0,13 \\
\hline 15 & 7,9 & 0,22 \\
\hline 30 & 15,8 & 0,26 \\
\hline 45 & 23,8 & 0,31 \\
\hline 60 & 31,7 & 0,33 \\
\hline
\end{tabular}

\section{Conclusões}

Através da dosagem controlada de ozônio, injetando diretamente na rede foi possível realizar a eliminação do composto tóxico 2,4 diclorofenol, medindo-se indiretamente, através do cloro residual liberado, em um constante aumento. A eficiência foi comprovada também pela eliminação do corante azul de metileno. Para uma concentração aproximada de $10 \mathrm{mg} / \mathrm{L}$ do contaminante a dose de ozônio necessária foi de aproximadamente $31.68 \mathrm{mg}$ de $\mathrm{O}_{3}$.

\section{Agradecimentos}

A FT-Unicamp e ao CNPQ elo financiamento da pesquisa.

${ }^{1}$ Hurtado, L., Amado-Piña, D., Roa-Morales, G., Peralta-Reyes, E., Martin del Campo, E., \& Natividad, R.2016, 